\title{
In defence of communitarianism philosophy: The contribution of moderate communitarianism to the formation of an African identity
}

\begin{abstract}
Author:
Walter P. Maqoma ${ }^{1}$

Affiliation:

${ }^{1}$ Unit for Reformational

Theology and the

Development of South

African Society, Faculty of

Theology, North-West

University, Potchefstroom,

South Africa
\end{abstract}

Corresponding author:

Walter Maqoma,

wpmaqoma@gmail.com

Dates:

Received: 25 Feb. 2019

Accepted: 29 Jan. 2020

Published: 01 Apr. 2020

How to cite this article: Maqoma, W.P., 2020, 'In defence of communitarianism philosophy: The contribution of moderate communitarianism to the formation of an African identity', Verbum et Ecclesia 41(1), a1984. https://doi. org/10.4102/ve.v41i1.1984

\section{Copyright:}

(c) 2020. The Authors. Licensee: AOSIS. This work

is licensed under the

Creative Commons

Attribution License.

Read online:

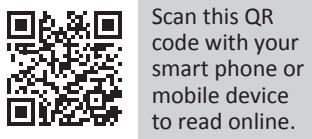

In a struggle to rediscover their identity beyond colonialism, Africans have sought to find a philosophy, which characterises their unique identity, beyond the anthropological horizons and Eurocentric perspectives of humanity, imposed upon them by the colonisers who defaced the personhood of an African. In this process, African philosophers have discovered that at the core of African philosophy is communitarianism philosophy. Thus, the personhood of an African is constituted by communal reality, which is influenced by communalism and communitarianism. In making a distinction between the two forms of communitarianism radical communitarianism and moderate communitarianism - this article makes a case for moderate communitarianism as an essential contributor to the formation of an African identity.

Intradisciplinary and/or interdisciplinary implications: Moderate communitarianism engenders an understanding, which takes the individuality of a person seriously, and locating that individual within a community which influences his/her identity; thus involving an integration of individual thought and communal tradition. Thereby, recognizing the dialectic of both the individual thought and communal tradition. Individual thought confirmed by insights that were a production of individual ingenuity and communal thought is known to be the concepts that are derived from traditional knowledge, and the moderation of both accounts for a balanced form of communitarianism, through the dialectic of both individual and community, which contributes to the formation of an African identity. Moderate communitarianism reflects the accurate thought of African philosophy, and accounts for a common feature within the diversity of different African communities. Therefore, moderate communitarianism is an essential contributor to the formation of an African identity!

Keywords: philosophy; theology; anthropology; humanity; community.

\section{Introduction}

It has become axiomatic to say, 'do not throw out the baby with the bathwater with the Baby', particularly within the discussion of ideas - whether to integrate or refute old or new ideas within the philosophical landscape, perhaps also the theological landscape, as the theological discipline is important for understanding identity, even African identity. Bediako (1999:1-10), in his book, Theology and Identity, noted that the question of identity is key to understanding the concerns of Christian theology in modern Africa as was the case in the 2nd century AD.

In a world that has been characterised by individualism, ${ }^{1}$ and has adopted Westernisation as a norm, the African communitarian identity has been refuted and critiqued as non-essential. As a result, the lack of acknowledgement of the particular identity of African people is disparaged. Hence, Tarus and Lowery (2017:305) have noted that the way identity is construed is crucial, because if it is defined in ways that lead to separation, isolation, radicalism or violence, then that identity will not welcome others and will also treat the 'outsider' with disrespect. The Western ideas of defining an African have in many instances led to unnecessary tensions amongst the African people, to an extent that WaWamwere (2003) defined this imposition as negative ethnicity. African people have been generally described as communal, as people who base their worldview ${ }^{2}$ on communal thinking.

1. The term individualism refers to the tendency across a broad array of spheres - politics, religion, psychology, philosophy - to make the individual person and the individual's fulfillment the locus of concern and measure of success' (Dufault-Hunter 2011:403).

2.The English word 'worldview' finds its origin from the German term weltanschauung, a word that comprises two words: welt, a German word that is translated as 'world' in English, and a second word anschauung, which means 'view' or 'outlook'; hence, the whole term is Word that is translated as 'world' in English, and a second word anschauung, which means 'view' or 'outlook'; hence, the whole term is
translated as worldview in English. It is an intellectual or a cognitive orientation of an individual or society, and it shapes how that translated as worldview in English. It is an intellectual or a cognitive orientation of an individual or society, and it shapes how that
individual or society interprets the world. A worldview refers to a wide world of perception, and the framework of ideas and beliefs through which an individual interprets the world and interacts with it. For a comprehensive definition of the concept, worldview, see Naugle (2002). 
African philosophy is generally defined as arising from a thought pattern, which is communal; therefore, African folk philosophy is a mediation of the thinking from the whole society, even though there may be key thinkers in the community, such as reputed sages, who are known for their wisdom; however, although these sages were individual thinkers, they also developed their wisdom by engaging with the community, and this dialectic gave birth to the African philosophy. $^{3}$

This philosophy came to be defined as communitarianism; hence, the communitarian concept of a person is considered as a standard view by many African thinkers. This view is predicated on the argument that personhood is constituted by communal reality as opposed to the Western view defined by unrestricted individual autonomy.

Thus, according to Menkiti (1984):

[T] he African view of man denies that persons can be defined by focusing on this or that physical or psychological characteristic of the lone individual. Rather, man is defined by reference to the environing community. (p. 171)

Moreover, Menkiti (1984:172) added: 'In the African view, it is the community which defines the person as person, not some isolated static quality or rationality, will, or memory'. Ikuenobe (2006) argued that communalism may be seen as a conceptual framework and foundation for African ideas, values, and thought and belief systems. So, African philosophy is characterised by communalism and communitarianism. Supporting this, Ikuenobe (2006) stated the following:

Both these concepts have their roots in the idea of a community: the idea of people living together as a group in a specific location and sharing some commonalities of history, ideology, belief system, values, lineage, kinship, or political system. Both concepts seem to emphasize, in various degrees, the normative idea that the community has some kind, degree, or level of moral or logical priority over the individual. (p. 1)

Moreover, to avoid confusion between these two concepts, Ikuenobe (2006:2) commented that 'some people may understand and use the notions of "communalism" and "communitarianism" differently'. Thus, Ikuenobe (2006) further attempted to define both these concepts by stating:

Communalism, for some, describes an informal sociological or anthropological phenomenon regarding a group of people living together and sharing common values and lineage or kinship. Such a group may or may not have a formal political or governmental structure that is based on such values or lineage. This idea may be contrasted with communitarianism, which describes for some, a formal or governmental structure and system in which people live together as a group, in virtue of sharing overriding set of moral, social, and political values or principles. The fundamental idea behind communitarianism, especially in the political sense,

3. Notwithstanding the false notion and the idea of a monolithic homogeneous society and the lack of appreciation for the multifacetedness within the African continent, and the lack of appreciation for the multifacetedness within the African continent, there are values and a sense of humanity represented throughout the continent North, East, South, West and in-between. To read more on the background to the Hermeneutics of Africanness, see Ngwena's (2018) text: What is Africanness? and Biko's (2019) text: Africa Relmagined, where he discusses the evolution of an African identity. involves an affirmation of the logical or moral priority of the community or its interests over those of individuals with respect to issues involving public policies. (p. 2)

Such a distinction is interesting in a sense that it shows there are commonalities between these two concepts, and also there are differences only with regard to the context in which each of these terms are used - the former is an informal orientation, whereas the latter is a formal orientation. Thus, because both these concepts have a common root in the idea of a community, this article uses both terms interchangeably as denoting the same idea, but mostly uses the term communitarianism. This article explores the idea that the right understanding of communitarianism takes the individuality of a person seriously in its articulation of communitarianism, and this position is referred to as moderate communitarianism. It is contrasted with radical communitarianism which, to some extent, ignores individual autonomy expressed through the ingenuity and creativity of the individual in its philosophical reflections.

One of the key proponents of moderate communitarianism is Gyekye (1997) who has maintained that moderate communitarianism is the accurate view of African philosophy, in contrast to radical communitarianism.

Moderate communitarianism was the result of an extreme or an 'unbalanced' view of communitarianism, which was considered radical because it did not acknowledge the rational autonomy of an individual in the construction of a community, and this undermining of the individual destroyed individual potential.

Morality in African cultures is, for the most part, communal, because moral principles and moral thoughts are fundamentally predicated on human well-being in the context of communal needs and interests. However, Ikuenobe (2006:3) noted that, 'communalism does not vitiate the possibility of rational moral education and autonomous or independent reasoning, or the ability of an individual to make autonomous rational choices'.

Therefore, the needs and interests of the individual must also be considered as important and integrated into the formation of common norms, as they contribute to the well-being of everybody in the community. Thus, this article presents both positions of radical communitarianism and moderate communitarianism through the descriptions of its key proponents and evaluates both these positions in light of the African experience in determining which position makes an accurate philosophic reflection of an African experience. Therefore, this article presents both the position of radical communitarianism and moderate communiteranism; however, it also makes a strong case for moderate communitarianism as the essential contributor to African identity!

\section{Radical communitarianism}

One of the key proponents of this school of thought is Tempels (1959). Through his work on Bantu philosophy, he 
describes Bantu ontology. ${ }^{4}$ This school of thought was perpetuated by Mbiti (1970) - considered to be the 'disciple' of Tempels. Another key figure of this 'movement' is Menkiti (1984), who was influenced by Mbiti (1970). They attempted to construct a philosophy, which is distinctly African.

There is a sense that radical communitarianism is based on the assumption that an individual is a person only if she/he belongs to a community and adheres to the rules and rituals of that community. Mbiti (1970:135) referred to this arrangement as kinship in traditional African communities, as he noted that, 'the deep sense of kinship, with all it implies, has been one of the strongest forces in traditional African life'. Further, Mbiti (1970) noted that it is kinship that controls social relationships between people in a given community: it governs marital customs and regulations, and determines the behaviour of one individual towards another. It is this sense of kinship that binds the community together and also sets the direction of the community.

According to Mbiti (1970), this system of kinship provides a framework for an African community to determine how an individual qualifies to be a person. Moreover, this system of kinship involves every aspect of community:

Indeed, this sense of kinship binds together the entire life of the 'tribe', and is even extended to cover animals, plants and nonliving objects through the 'totemic' ${ }^{5}$ system. This it is which largely governs the behaviour, thinking and whole life of the individual in the society of which he is a member ... The kinship system is like a vast network stretching laterally (horizontally) in every direction, to embrace everybody in any given local group. This means that each individual is a brother or sister, father or mother, grandmother or grandfather, or cousin, or brother-in-law, uncle or aunt, or something else, to everybody else. (pp. 135-136)

Kinship allows individuals to identify with everybody belonging to the community, and so everybody is related, and this connection is likened to family members. Mbiti (1970:136) further suggested that the kinship system also extends vertically to include the departed and those yet to be born. These - the dead and the unborn - are very important part of the community, and in some way they are venerated; that is why Mbiti (1970:139) in his discussion of kinship made a few remarks about these groups of people; he also noted that the family also included the departed relatives whom we have designated as the living-dead.

These are, as their names imply, 'alive' in the memories of their surviving families and are thought to be still interested

4.Matolino (2009:161) elucidated that Tempels sees the individual as essentially heterogenous in ontological relations with her community: 'The living "muntu" is in a relation of being to being with God, with his clan brethren, with his family and with his descendants. He is in a similar ontological relationship with his patrimony, His land with all that it contains or produces, with all that grows or lives on it (Tempels 1959:66-67). Matolino (2009) further added that this ontologica relationship with other beings and things involves moral achievements and worthiness. 'In order for one to be seen as a person, she ought to exhibit certain moral worth or attainment' (Matolino 2009:161).

5.Totemic - an adjective derived from the word 'totem', which is defined as 'a natural object or animal believed to have spiritual meaning and adopted as an emblem by object or anir ad by a particular society' (Oxford Paperback Dictionary and Thesaurus 2009.979). Corduan (2012.214) explained that 'totemism is not an intrinsically religious institution, although it cannot be totally divorced from the overall religion of any particular tribe in question. Its primary functions are sociological only'. in the affairs of the family to which they once belonged in their physical form. Moreover, the 'African concept of the family also includes the unborn members who are still in the loins of the living' (Mbiti 1970:139). Mbiti moves ahead to destroy the autonomous individual who is rational in light of the community.

Man's ontology is derived from the existence of the community; hence, Mbiti (1970:141) asked: 'what then is the individual and where is his place in the community?' $\mathrm{He}$ answers this question by suggesting that the individual does not and cannot exist alone except corporately.

He owes his existence to other people, including those of past generations and his contemporaries. He is simply part of the whole. Mbiti (1970) took this step further by concluding the following:

The community must therefore make, create or produce the individual, for the individual depends on the corporate group. Physical birth is not enough: the child must go through rites of incorporation so that it becomes fully integrated into the entire society. (p. 141)

Menkiti (1984) added to this by idiomatically noting that:

[J]ust as the navel points men to umbilical linkage with generations preceding them, so also does language and its associated social rules point them to a mental commonwealth with others whose life histories encompass the past, [the] present, and [the] future. (p. 172)

These social rules are introduced to individuals at every stage of their lives. Thus, according to Mbiti (1970):

These rites continue throughout the physical life of the person, during which the individual passes from one stage of corporate existence to another. The final stage is reached when he dies and even then he is ritually incorporated into the wider family of both the dead and the living ... Only in terms of other people does the individual become conscious of his own being, his own duties, his privileges and responsibilities. (p. 141)

Therefore, the individual is only an 'it' until it has been incorporated through the rites and rituals of the community. The problem with the 'it' status of an individual, which characterises the unborn and the dead, is that it confuses the whole description of attaining personhood because such a phenomenon has to present the degree to which the 'it' status of the unborn differs from the 'it' status of the dead.

\section{To make a point, Menkiti (1984) stated that:}

[F]or the ancestral dead are not dead in the world of spirits, nor are they dead in the memory of living men and women who continue to remember them, and who incessantly ask their help through various acts of libation and sacrificial offering. (p. 174)

Later on, Menkiti (1984:174) remarked that 'the dead still retain their personhood and are, as a matter of fact, addressed by their various names very much as if they were still at center stage'. This sounds as if the 'it' status of the dead is superior to the 'it' status of the unborn because the dead 
retains the personhood it had attained between the two polarities of the unborn and the dead; perhaps, this sounds ludicrous, incongruous and impractical.

Further, Menkiti (1984:175) contradicted himself when he noted that, 'it is perhaps worth noting that this phenomenon of a depersonalised status at the two polarities of existence makes a great deal of sense given the absence of moral function'. How can the dead at one time retain its status of personhood and suddenly lose her/his moral capacity still in the process of being dead? Nevertheless, the process of incorporation is a necessary part of becoming a person in the African context, and as a result an individual becomes a person only when she/he is a part of the community.

\section{Thus, according to Menkiti (1984):}

$[W]$ ithout incorporation into this or that community, individuals are considered to be mere danglers to whom the description 'person' does not fully apply. For personhood is something which has to be achieved, and is not given simply because one is born of human seed. (p. 172)

To be born does not automatically afford one the opportunity or the privilege - to be a person according to the radical views of communitarianism, as Menkiti (1984) added that:

Thus, it is not enough to have before us the biological organism, with whatever rudimentary psychological characteristics as seen as attaching to it. We must also conceive of this organism as going through a long process of social and ritual transformation until it attains the full complement of Excellencies seen as truly definitive of man. And during this long process of attainment, the community plays a vital role as catalyst and as prescriber of norms. (p. 172)

Mbiti's (1970) conception of African philosophy is summarised in the statement, as cited by Menkiti (1984:171), which says: 'I am because we are, and since we are, therefore I am'. Menkiti (1984) developed this further by stating that:

$[O]$ ne obvious conclusion to be drawn from this dictum is that, as far as Africans are concerned, the reality of the communal world takes precedence over the reality of individual life histories, whatever these may be. And this primacy is meant to apply not only ontologically, but also in regard to epistemic accessibility. (p. 171)

Therefore, according to Ikuenobe (2006):

Moral principles in African cultures function as semantic and epistemic criteria. They are predicated on the attempt to address the fundamental question, 'what ought we to do?' as opposed to 'what ought I to do?' or 'how ought we to behave?' Such thinking is fundamentally normative and applied in nature, and it is expressed in the form of a means-end scheme. As a result of the communal context in African cultures, moral values, virtues, and principles are encoded in, learned, and taught informally through narratives, folklore, parables, proverbs, mentoring, and the modelling of behaviours by elders. (p. 3)

Thus, 'it is in rootedness in an ongoing human community that the individual comes to see himself as man' (Menkiti 1984:172). However, this view of radical communitarianism falls short of presenting an accurate view of the African understanding of man or personhood. Hence, other African philosophers, in response to this, developed the notion of moderate communitarianism.

\section{Moderate communitarianism}

One of the key drivers of this 'movement' of moderate communitarianism is Gyekye (1997), who also responded to some of the works of radical communitarians. After citing Mbiti's (1970) familiar dictum: 'I am because we are, and since we are, therefore I am', as representative of the basis of radical communitarians, Gyekye (1997) responded by noting that:

[T] hese descriptions of African culture make clear communitarian nature. What they do not make clear, however, is what type of communitarian notion is, or can be said to be, upheld in the African moral and political theory: radical or moderate? (p. 37)

In his defence of moderate communitarianism, Gyekye (1997) expressed his observation of the relation between the individual and the community by stating that:

The most appropriate type of relation that should exist between the individual and society has been an intractable problem for social and political philosophy. The problem arises because we believe, on one hand, that the individual human being has autonomy, freedom, and dignity - values that are considered most worthwhile and ought therefore to be respected by the society; we believe, on the other hand, that the individual not only is a natural member of the human society but needs society and all that it makes available for the realization of the individual's potential, and for living a life that is most worthwhile. (p. 35)

It is interesting to notice that moderate communitarianism when contrasted with radical communitarianism, which begins its focus on the community and afterwards, perhaps, considers the individual - begins by focussing on the individual and what he/she possesses outside being part of the community, as Gyekye has noted above that the individual possesses characteristics of autonomy, freedom and dignity, and he adds to this by noting that, 'questions raised by intellectuals, especially the moral and political philosophers amongst them, relate, in this connection, to the metaphysical and moral status of a person (or self)' (Gyekye 1997:35). What is remarkable here in Gyekye's construction of communitarianism is that he moves its status from the level of ethical construction - which is evident in radical communitarianism - to the level of metaphysics, which is a foundational element in philosophic discourse.

\section{Gyekye (1997) further stated that:}

[T] he metaphysical questions are about whether a person, even though she lives in a human society, is an atomic, self-sufficient individual who does not depend on her relationships with others for the realization of her ends and who has ontological priority over the community. (p. 35)

Therefore, moderate communitarianism takes into consideration the potential of individuals because it is the individuals that make up the community, and, realistically 
speaking, any idea in its primal form is a construction of an individual, although through mediation with other members of the community, it is developed and eventually adopted as a norm that belongs to the community. Thus, moderate communitarianism involves an integration of individual and communal thought. Communal thought is known to be the concepts that are derived from traditional knowledge, and individual thought is confirmed by insights that were a production of individual ingenuity. Wiredu (1991) observed the following:

There is a recognition that among the traditional folks of Africa uninfluenced by modern education, there are genuine philosophers, people capable of fundamental reflection on man and the world. Such people are able to subject the folk philosophies of their own communities to criticism and modification. Earlier students of African traditional philosophy do not seem to have noted the existence of this class of traditional thinkers; they seem to have only sought information as to the folk worldviews of various African peoples. And as far as they were concerned, all those who gave them information were simply 'informants'. The information they gathered in this way, without further ado, was labelled 'African philosophy', and this is largely responsible for the impression that African philosophy is a monolithic body of non-argumentative communal beliefs, and nothing else. (p. 95)

Wiredu (1991), in the above statement, implied that African philosophy has a component of communal thought; however, there is more than communal thought in the construction of African philosophy because these African communities that applied these folk philosophies had great individual thinkers who contributed insights to the production of these folk philosophies. Therefore, the component of individual thought contributes immensely to the construction of African philosophy.

\section{Therefore, according to Wiredu (1991):}

There is an intimate relation between the thought of the individual, traditional sage-philosophers and the communal world outlook of their people. The communal philosophy provides the point of departure for the sage-philosopher. It provides, in fact, his philosophical education and must, in many ways, determine his theoretical options. On the other hand, a little reflection must show that the communal thought itself is the pooling together of these elements of the thought of the individual philosophers of the community that remain stuck in the common imagination. (p. 96)

In this line of thought, Gyekye (1997), in his defence of moderate communitarianism, continued to respond to Mbiti"s and Menkiti's constructions of communitarianism by stating that:

[W] hile I believe that the metaphysical construal of personhood in African thought such as Menkiti's and Mbiti's is overstated and somewhat misleading, such views or beliefs did provide the ideological groundwork for the so-called African socialism. (p. 37)

The above statement already proves that Gyekye (1997) does not totally disregard Menkiti's and Mbiti's assertions of communitarianism-whichbelongtoradicalcommunitarianism - but that he acknowledges what is significant about their constructions, and rectifies them where necessary. Gyekye (1997) further stated that inasmuch as the scholars such as Menkiti and Mbiti do not appear to have fully recognised the status and relevance of individual rights, their views patently model thenotion of radical and unrestricted communitarianism. Thus, this article also, in taking the position of moderate communitarianism, considers the positive remarks of radical communitarianism, for both these are not necessarily opposed to each other; such internal scrutiny applied within every philosophy is necessary for the development of any idea.

What is common in these two schools of thought is 'the fact that the individual human being is born into an existing community first', and according to Gyekye (1997):

$[T]$ his communitarian conception of the person implies that community life is not optional for the individual. It also suggests that he cannot - perhaps should not - live in isolation from other persons, that he is naturally oriented toward other persons and must have relationships with them. (p. 38)

However, this must not be interpreted as suggesting that because the individual is born into a community, then his personhood should be derived from the community; hence, Gyekye (1997:38) commented that 'this attribute of relationality or sociality in some way makes up for the limited character of the possibilities of the individual, a limitation that whittles away the individual's self-sufficiency'. As a result, potential of most African people is not unleashed, and sadly most of it ends in the grave because most individuals in Africa are forced to conform to community norms that do not acknowledge their individuality, and prioritises the ontology of the community over that of the individual. 'Yet, it might be supposed that if a community consists of individuals sharing interests and values, would this not imply that the individual has priority over the community?'(Gyekye 1997:38). To answer this, Gyekye (1997) quoted an Akan proverb, which illustrates the answer, by stating:

'One tree does not constitute a forest'. That is to say, for there to be a forest, there will have to be several individual trees ... Although communities can vary in size, not even the smallest is constituted by only one individual. A community emerges, that is, comes into existence, according to the proverb, with the congregation of several individuals: the priority of the individual, vis-a-vis the derived status of the community, appears implicit in this proverb ... On the analogy of the proverb, the reality of the community is derivative: secondary, not primary. (p. 39)

The individual ontology or philosophy concerned with the nature of being must have pre-eminence over the ontology of the community not only because the community is made of individuals who are autonomous but also because individuals seem to survive in any environment, and because our world is constituted by many different communities, that one individual is able to adapt to any given situation. Thus, Gyekye (1997) stated:

People are therefore members of many different communities, different in size and operating at different levels, and are likely to develop different aspects of their sociality in the various communities. Consequently, a person's well-being may be tied up 
with the existence of social relationships at many different levels, some of which extend far beyond her proximate community. (p. 43)

What constitutes communitarianism? Gyekye (1997) helped to clarify that it is more than a community made by individuals:

Communitarianism immediately sees the individual as an inherently communal being, embedded in a context of social relationships and interdependence, never as an isolated individual. Consequently, it sees the community as a reality itself - not a mere association based on a contract of individuals whose interests and ends are contingently congruent, but as a group of persons linked by interpersonal bonds ... What distinguishes a community from a mere association of individuals is the sharing of an overall way of life. (p. 42)

For this community to flourish, it must allow the individuals who are part of it to exercise rational autonomy, and use their freedom to think of new ideas to contribute to the already existing community for the betterment of all individuals. Thus, rational autonomy is indispensable for a flourishing society because it allows individuals to question existing social norms to see if they are still relevant or if they have been contributing positively to the community, because some communities have been driven and characterised by social norms that treated some of the individuals without human dignity, and these norms were accepted by many on the grounds of compliance to the community's social norms (for instance, apartheid). Therefore, it is important to highlight the place of the individual as a person in African thought, irrespective of whether that individual has been incorporated through the rites and rituals practiced in a community or not.

Nevertheless, the community must have as its goal an intention to help enhance the growth of strong individuals who are able to reason rationally, so that the community does not become abusive, for some communities could be characterised by systems that are harmful, as Gyekye(1997) stated that:

$[T]$ here are some relationships that can surely be said to be positively harmful to the individual's development and interests, relationships, for instance, that are built on slavery, domination, humiliation, or discrimination. (p. 42)

It is interesting to realise that most of these imperfections in the institution of a community are a reflection of defective individual thought, which is able to persuade others to support such an immoral system.

In the same manner, the destruction of such immoral systems was begun by individuals who used their rational autonomy and challenged the immoral and unjust systems, and also challenged the other members of the community to evaluate the accepted norms of society and discard them if they were harmful to human flourishing.

Thus, the community must develop individuals with high moral standards and must also encourage individuality. Hence, 'the community constitutes the context for the creation and development of a person's identity. A person comes to know who she is in the context of relationships with others' (Gyekye 1997:43).

\section{Contending for communitarianism}

In order to confirm the significance and primacy of individual ontology in African thought, Gyekye (1997:40) cited a few African proverbs to strengthen his argument, for example: 'The clan is like a cluster of trees which, when seen from afar, appear huddled together, but which would be seen to stand individually when closely approached'. Thus, in drawing an analogy between the clan (or community) and a cluster of trees, this proverb says that even though some of the branches of a tree may touch other trees, the individual tree is separately rooted, has its own separate identity and is therefore not totally absorbed in the cluster. Therefore, according to the proverb, individuality is not obliterated by membership in a human community.

Hence, moderate communitarianism's view of personhood is clearer and seemingly adequate in comparison to that of radical communitarianism; Gyekye (1997:49), in outlining the distinction between the two, noted that, 'Menkiti's analytic account of personhood in African thought is befogged with confusions, unclarities, and incoherencies' ${ }^{6}{ }^{6}$

Moderate communitarianism first of all considers every individual as a human being - not as an 'it' according to radical communitarianism - and being a human being already affords one the potential to be a person. Therefore, personhood is another level of being a human being. Hence, Gyekye (1997) stated:

The individual to whom the judgement 'he is not a person' is applied would be one whose conduct is known to the community to be generally unethical, not one who occasionally experiences moral lapses or failure of moral commitment. There is no implication, however, that an individual considered 'not a person' loses her rights as a human being or that she loses her citizenship or that she ceases to be an object of moral concern from the point of view of other people's treatment of her. Only that she is not a morally worthy individual. (p. 50)

Therefore, personhood depends on the individual's growth in character, which is reflected through the exercise of moral capacity. Every individual - whether a child or an adult - has the potential to be a person and that personhood is intrinsic in every individual, for every individual is a human being. To emphasise, no individual is an 'it', and an individual does not have to practice the rituals and rites set by the community for incorporation to be a person, but rather, personhood is intrinsic.

\section{Hence, according to Gyekye (1997):}

$[W]$ hile children are actual human beings and are members of the community, they are persons only potentially and will achieve the status of personhood in the fullness of time when they are able to exercise their moral capacity. (p. 50)

6. However, Matolino (2009:164) is not convinced by Gyekye's (1997) statement that Menkiti's (1984) account is internally confused and incoherent as he (Gyekye) does Menkiti's (1984) account is internally confused and incoherent as he (Gyekye) does not show where the confusion or incoherence lies in Menkiti's (1984) account: ' think an efficacious objection to Menkiti's version would be to claim that the radica version is false for some reason or other. Gyekye attempts to show that moderate communitarianism is at least true for the Akans but immediately contradicts himsel when he lays bare the essential beliefs of any form of communitarianism. It appears as if the move to claim the falsehood of radical communitarianism cannot be made'. 
And this is possible through both individual autonomy and communal practices.

Moderate communitarianism emphasises individual autonomy as a priority because, it seems that the fact that a human being is a social being is already a given; however, it is still secondary.

\section{According to Gyekye (1997):}

Now, despite the natural sociality of the human being, which at once places him in a system of shared values and practices and a range of goals, there are, nevertheless, grounds for maintaining that a person is not fully defined by the communal or cultural structure ... besides being a social being by nature, the human individual is, also by nature, other things as well. By 'other things', I have in mind such essential attributes of the person as rationality, having a moral sense and capacity for virtue and, hence, for evaluating and making moral judgements: all this means that the individual is capable of choice. (p. 53)

Gyekye (1997) referred to these essential attributes as a 'mental feature'; and this 'mental feature' distinctly belongs to the individual. Hence, 'it is not the community that creates this mental feature: This feature would not be natural if it were created by the community. The community only discovers and nurtures it' (Gyekye 1997:53). Moreover, Gyekye (1997) stated:

If the mental feature plays any seminal role in the formation and execution of the individual's goals and plans, as indeed it does, then it cannot be persuasively argued that personhood is fully defined and constituted by the communal structure or social relationships. There is no denying the community's role in the complex process involved in the individual's realisation of her goals and aspirations, though; yet, even so, the communal definition or constitution can only be partial. (p. 53)

\section{Conclusion}

Supposedly, there is a dialectic process involved between the expression of the intrinsic, essential attributes that the individual possesses, and the influence of the community's norms, values and practices, for the formation and execution of personhood. Let me conclude by saying that all the attributes that are necessary for transforming a human being into a person - like those already mentioned in the above quotation - already exist potentially inside every human being, hence intrinsic, and are not acquired externally. If these attributes were acquired externally, then the essence of moral capacity would diminish because people find themselves in different communities, and different communities demand compliance to different norms and this would make us resort to relativism, which is incoherent.

Thus, moderate communitarianism provides a balanced view of communitarianism in that it acknowledges both individuality and community and sees the effectiveness of both as necessary for personhood. Hence, it takes into consideration both ancient wisdom and current thinking of philosophers, as representative of individuality, and the existence of a community as it evolves, and through this mediation, personhood is formed.
According to Gyekye (1997):

Moderate or restricted communitarianism gives accommodation to communal values as well as to values of individuality, to social commitments as well as to responsibilities to oneself. In its basic thrust and concerns, it pays due, and adequate, regard to responsibilities to the community and its members and would consider the so-called supererogatory acts as belonging to the category of moral responsibilities, though not to the detriment of individual rights whose existence and value it recognizes, or should recognize, and for a good reason. (p. 76)

Moderate communitarianism reflects the accurate thought of African philosophy and accounts for a common feature within the diversity of different African communities. Therefore, moderate communitarianism is an essential contributor to the formation of an African identity!

\section{Acknowledgements}

This article resulted from the post-doctoral research of Walter Phumzile Maqoma, under the supervision of Vhumani Magezi, in the Faculty of Theology, at the North-West University.

\section{Competing interests}

The author declares that he has no financial or personal relationships which may have inappropriately influenced him in writing this article.

\section{Author's contributions}

I declare that I am the sole author of this research article.

\section{Ethical consideration}

This article followed all ethical standards for a research without direct contact with human or animal subjects.

\section{Funding information}

This research received no specific grant from any funding agency in the public, commercial or not-for-profit sectors.

\section{Data availability statement}

Data sharing is not applicable to this article as no new data were created or analysed in this study.

\section{Disclaimer}

The views and opinions expressed in this article are those of the author and do not necessarily reflect the official policy or position of any affiliated agency of the author.

\section{References}

Bediako, K., 1999, Theology and identity: The impact of culture upon Christian thought in the second century and in modern Africa, Wipf \& Stock, Eugene, OR. Biko, H., 2019, Africa reimagined, Jonathan Ball, Cape Town.

Corduan, W., 2012, Neighboring faiths, 2nd edn., IVP Academic, Downers Grove, IL. Dufault-Hunter, E., 2011, 'Individualism', in J.B. Green (ed.), Dictionary of scripture and ethics, pp. 403-405, Baker, Grand Rapids, MI. 
Gyekye, K., 1997, Tradition and modernity: Philosophical reflections on the African experience, Oxford University Press, New York.

Ikuenobe, P., 2006, Philosophical perspectives on communalism and morality in African traditions, Lexington Books, Oxford.

Matolino, B., 2009, 'Radicals versus moderates: A critique of Gyekye's moderate communitarianism', South African Journal of Philosophy 28(2), 160-170. https://doi.org/10.4314/sajpem.v28i2.46674

Mbiti, J.S., 1970, African religions and philosophies, Anchor Books, New York.

Menkiti, I.A., 1984, 'Person and community in African traditional thought', in R.A. Wright (ed.), African philosophy: An introduction, pp. 171-181, University Press of America, Lanham, MD.

Naugle, D.K., 2002, Worldview: The history of a concept, Eerdmans, Grand Rapids, ML.
Ngwena, C., 2018, What is Africanness? PULP, Pretoria.

Tarus, D.K. \& Lowery, S., 2017, 'African theologies of identity and community: The contributions of John Mbiti, Jesse Mugambi, Vincent Mulago, and Kwame Bediako', Open Theology 3(1), 305-320. https://doi.org/10.1515/opth-2017-0024 Tempels, P., 1959, Bantu philosophy, Presense Africaine, Paris.

WaWamwere, K., 2003, Negative ethnicity: From bias to genocide, Seven Stories Press, New York.

Waite, M. \& Hawker, S. (Eds.) 2009. Oxford Paperback Dictionary and Thesaurus $3^{\text {rd }}$ Edition. Oxford: Oxford University Press.

Wiredu, K., 1991, 'On defining African philosophy', in T. Serequeberhan (ed.), African philosophy: The essential readings, Paragon House, New York. 